\title{
HISTORICAL CARTOGRAPHIC OVERVIEW AND CARTOGRAPHIC ANALYSIS OF THE GEOLOGICAL MAP OF TRANSYLVANIA BY HAUER (1861)
}

\author{
Enikö KORODI ${ }^{1}$, Thomas HOFMANN ${ }^{2}$
}

DOI: $10.21163 / G T \_2016.111 .06$

\begin{abstract}
:
One of the most most outstanding achievement of the Transylvanian geological mapping activity of the mid- nineteenth century, namely the overall geological map of Transylvania by Hauer (1861) represents an important part of our cartographic heritage. Therefore, the aim of this study is on the one hand, to offer a brief survey about the historical cartographic overview of the map with special respect to the geological mapping activity of Transylvania in the midnineteenth century. On the other hand, the paper summarizes the cartographic analysis which has been made in order to geo-reference the map in its initial projection and geodetic datum. The rectification has been performed in Global Mapper v16.1 using all the crossings of the grid lines, while the geometric accuracy of the map has been analysed with the MapAnalyst 1.3.23 software application. This analysis is necessary when the goal is to extract geological information from several geological maps from different periods in order to compare the old geological data with modern ones and to make possible the tracking of the evolution of geological knowledge in time.
\end{abstract}

Key-words: Transylvania, historical cartography, old geological map, map projection, georeference

\section{INTRODUCTION}

Old maps in general represent an important part of our cultural heritage. In addition, they are more and more often used as sources of information for historical studies (Jenny \& Hurni, 2011), especially due to the rapid development of GIS software and applications. Old geological maps in a unique way reflect the state of geological knowledge characteristic to a specific period.

Geological maps are special-purpose thematic maps: they show, on topographic base maps, information regarding the petrographic composition, structure and stratigraphic succession (succession in time) of the geological features at and under the land surface consequently they allow the geological orientation and cognition of a certain area (Brezsnyánszky, 2007). The distribution of the geological features is represented by a system of specific symbols: a combination of colours, lines and special symbols unique to geological maps. Colours and symbols also indicate the age of the geological formations (Brezsnyánszky, 2001: 4-8; Brezsnyánszky, 2007).

The old geological maps (in a wider sense the previous geological observations and researches) are of exceptional practical importance - if not fundamental- especially in those areas where the excavations are scarce. However, for an old map to be a reliable source of information for the present researches it is required to know and to take into

\footnotetext{
${ }^{1}$ Babeş-Bolyai University, Faculty of Geography, 400006 Cluj-Napoca, Romania, korodi.eniko@yahoo.com

${ }^{2}$ Geological Survey of Austria, 1030 Vienna, Austria, thomas.hofmann@geologie.ac.at
} 
consideration its topographic accuracy. Therefore, the analysis and exploration of the topographic basis (projections, geodetic datums, prime meridians) must be done in order to geo-reference an old geological map (Galambos, 2009; Galambos, 2010a). The estimation of the topographic basis of an old geological map can be often difficult, and requires cartohistorical and carto-bibliographic knowledge (Jenny \& Hurni, 2011), especially if the map - as geological maps in general (except for some large scale maps) - hadn't an independent geodetic or topographic survey (Galambos, 2010a; Galambos, 2010b), but it was compiled using as basis a pre-designed topographic or regional map on which the geological data were subsequently drawn.

Once the map is geo-referenced, further GIS applications can be performed: e.g. extraction of information (data) for quantitative or qualitative studies; overlapping georeferenced geological maps from different periods or combine them with other geoinformation datasets (e.g. SRTM datasets (Werner, 2001; Timár, Telbisz \& Székely, 2003)) etc. Therefore, the investigation of the topographic accuracy together with the study of the geological content of the maps makes possible the analysis and comparison of old geological data with modern ones, and consequently the tracking of the evolution of geological knowledge in time.

The aim of this paper is to present the geological map of Transylvania by Hauer (1861) - as an important part of our thematic cartographic heritage - with special respect to the historical cartographic background (the geological mapping activity of Transylvania in the mid-nineteenth century), to the geological content (especially the legend) and topographic basis of the map, as well as to its cartographic analysis (the geo-referencing methods and results).

\section{HISTORICAL CARTOGRAPHIC OVERVIEW}

\subsection{The development of the geological mapping of Transylvania in the mid-nineteenth century}

In the mid-nineteenth century Transylvania was a part of the Habsburg Empire therefore, its geological mapping activity was strongly determined by this type of activity of the Imperial and Royal Geological Institute ("k. k. geologische Reichsanstalt") founded in Vienna in 1849. These were the times when the geological mapping went through a significant development process, furthered by the economic booming of the Monarchy, since the industrial revolution required science-based geological researches (Pentelényi \& Síkhegyi, 2007) and the Court Chamber set a high value on the scientific researches related to the sources of raw materials. On the other hand, the geological mapping activity was stimulated by the fact that the scientific conception of geology - as a separate branch of science - had completed itself by then, and simultaneously it developed its own cartographic representation methods most suitable for the purpose (Brezsnyánszky \& Turczi, 1998; Barczikayné Szeiler et al., 2009).

The geological surveying for overall mapping of the Habsburg Empire on a scale of 1:288,000 had been carried out in the years 1856-1862 (Hauer, 1863: 3-6; Brezsnyánszky, Dudich \& Schedl, 1999), in addition to the systematic sheet-by-sheet geological mapping on a scale of $1: 144,000$ that began in 1851 (Haidinger, 1859) - based on the deduced 1:144,000 detailed maps ("Spezialkarten") (Jankó, 2007: 76-80) of the $2^{\text {nd }}$ Military Survey (1806-1869, in Transylvania: 1853-1873). However, the topographic map sheets on the scale of 1:144,000 and 1:288,000 related to Transylvania were still not available in that time (Brezsnyánszky, 1996). Therefore, here the overall geological mapping began first on 
a scale of 1:432,000 ("Straßenkarten") (Brezsnyánszky, Dudich \& Schedl, 1999), then based on the deduced general maps of the $2^{\text {nd }}$ Military Survey on a scale of 1:576,000 (“Generalkarten") (Jankó, 2007: 82-83). This mapping activity continued just later on a scale of 1:288,000, after the publication of the General Map of Transylvania (MGI, 1863). In Transylvania the geological surveying for overall mapping had been carried out in the years 1859-1860 (Hauer, 1863: 3-6) directed by Franz Ritter von Hauer (1822-1899), chief geologist of the Imperial and Royal Geological Institute at that time. The mapping work was performed with the participation of such accomplished Austrian geologists as Ferdinand von Richthofen (1833-1905), Dionys Štur (1827-1893) and Guido Stache (1833-1921), in other words, the forefront of the Imperial and Royal Geological Institute of the Habsburg Empire (Bachl-Hofmann, 1999). In the mapping activity also took part Albert Bielz (1827-1898), naturalist of Transylvanian origin (actually from Sibiu, Hermannstadt at that time), who increased the efficiency of this work not only with his expertise, but also with his first-hand knowledge of the territory (Hauer, 1863: 3-6).

\subsection{The field works for the map of Transylvania by Hauer (1861) in the years 1859- 1860}

The field works for this map were carried out in the summers of 1859 and 1860. As a result of mapping activity of the year 1859 Hauer presented at the Imperial and Royal Geological Institute ("k.k. geologische Reichsanstalt") on $29^{\text {th }}$ November 1859 a general geological map of Eastern Transylvania ("Uebersichtskarte des östlichen Siebenbürgen"). This map was the result of the mapping work that Hauer carried out together with Ferdinand von Richthofen and Albert Bielz in the summer of 1859 (Hauer, 1859; Hauer, Bielz \& Hörnes, 1860). They used, as topographic basis, a photographic copy ("photographische Copie") of a map of Transylvania ("Operationskarte des Grossfürstenthums Siebenbürgen") on a scale of 1:230,400 which was kept in the Institute of the Military Geography ("k. k. Militärgeographisches Institut"). They used this map in order to mark their routes and the numerous measurements of the hypsometry (=levelling). However, this map was too dark for geological information. Thus, they used a map of Transylvania edited by Bielz in 1854 on a scale of 1:460,800 (Hauer, 1859). Although this map was considered too "small" for the purpose ("für diesen Zweck etwas klein"), they used it anyway because all the settlements and also the terrain were represented in it.

Hauer and his colleagues started the mapping work in the surrounding area of Sibiu (Hermannstadt) and they continued moving eastward, towards Brașov (Kronstadt) where they were obliged to do more profound observations due to the presence of some "complicated" geological structures ("complicirte geologische Structur der Umgebung einen längeren Aufenthalt nöthig machte"). Afterwards, they mapped the Harghita volcanic chain and finally the Transylvanian part of the Eastern Carpathians.

Richthofen mapped mainly the volcanic rocks and some younger Tertiary sediments; he mapped alone also the region located North of Bistrița (Bistritz) up to Baia Mare (Nagybánya) region. Hauer mapped some older sedimentary rocks in the Southern and Eastern part of the mapped region. In general, they distinguished in the map 17 different geological units (Hauer, 1859: 181-183).

On a meeting held at the Geological Survey on $20^{\text {th }}$ November 1860 , Hauer presented to the auditorium the final version of the geological map of Transylvania (Hauer, 1860b). He reported that the mapping work had been carried out during the previous two summers with the participation of Albert Bielz, Ferdinand von Richthofen, Guido Stache and Dionys Stur. Bielz was financially supported by Prince Friedrich von Liechtenstein 
(1807-1885), Governor of Transylvania (1858-1861) and Rudolf Count of Amadei (18141898). The final results were drawn from the map by Bielz on a scale of 1:430,000 (Hauer, $1860 \mathrm{~b})$ to the topographic map on a scale of 1:576,000 compiled by Franz Fischer (1860). This last one was used for editing the geological map in which Hauer distinguished 30 different rock types this time. Hauer also heightened that among all the maps that had been compiled before (namely the maps by Beudant, Boué, Lill von Lilienbach, Partsch, Grimm, Haidinger, Bielz, and Knöpfler) the map by Paul Partsch (1791-1856) plotted during a ten months' visit in 1826 and 1827 had been the best work until then (Hauer, 1860b).

Hauer also noticed the scientific progress of his map. Thus, they could make a distinction between metamorphic rocks ("krystallinischen Schiefergesteine") and magmatic rocks ("krystallinischen Massengesteinen"); they were also able to trace Triassic and Liassic rocks ("Nachweisung von Trias- und Liasgesteinen"); at the same time they brought the large distribution of Cretaceous rocks ("Verzeichnung ausgedehnter Massen von Kreidegebilden") in relief. An important emphasis was placed on various volcanic rocks ("Sonderung der trachytischen Tuffe und Conglomerate von den festen Trachyten und die Unterscheidung der letzteren in drei der petro-graphischen Beschaffenheit und dem Alter nach verschiedene Gruppen") and on the division of some levels of the Eocene Formation as well as on the "Karpathensandstein" and the "Karpathenkalk".

These geological investigations were based on topographical measurements which were presented at the Imperial Geographical Society. Hauer (1860a) reported at a meeting of the Imperial Geographical Society (" $k$. $k$ geographische Gesellschaft") on $6^{\text {th }}$ March 1860 about trigonometric levelling measurements of Transylvania. Thus we find in Hauer work (1860a) measurements data from literature as well as from own measurements ("Gemessene Höhen") that he made in the summer of 1859. The latter allows us to track his itineraries in Transylvania (Hauer, 1860b: 14-36).

At the same time we can mention that Hauer also (1861) reported on a meeting of the Imperial Geographical Society on $4^{\text {th }}$ December 1860 about trigonometric levelling measurements made in Transylvania together with Stur and Stache in the summmer of 1860. It is possible once again to track the routes of the geologists with these measurements data.

\subsection{The overall geological map of Transylvania by Hauer (1861)}

As a result of this geological mapping activity, Franz Ritter von Hauer published in Hermannstadt (Sibiu) the overall geological map of Transylvania on a scale of 1:576,000 (Hauer, 1861) (Fig. 1), and plotted, with the involvement of Guido Stache, the first geological monograph of the Transylvania with the title "Geologie Siebenbürgens" (Hauer $\&$ Stache, 1863). This outstanding synthesis was practically written as explanatory notes for the map. However, Hauer drafted in the preface that the aim of the authors was more than that: they intended to present an overall view of the geology of Transylvania from that time, reflecting not only their but also the predecessors' research results and geological knowledge (Hauer, 1863: 3-6). Therefore, in editing the map and the monograph, the authors relied on the entire previous geological bibliography (339 works of reference!), as well as on the previously plotted maps related to this area, especially on an extremely detailed field-report and a map by Paul Partsch (1791-1856) from 1827, which nevertheless have remained in manuscript form (Hauer, 1863: 3-6; Hauer \& Stache, 1863). 


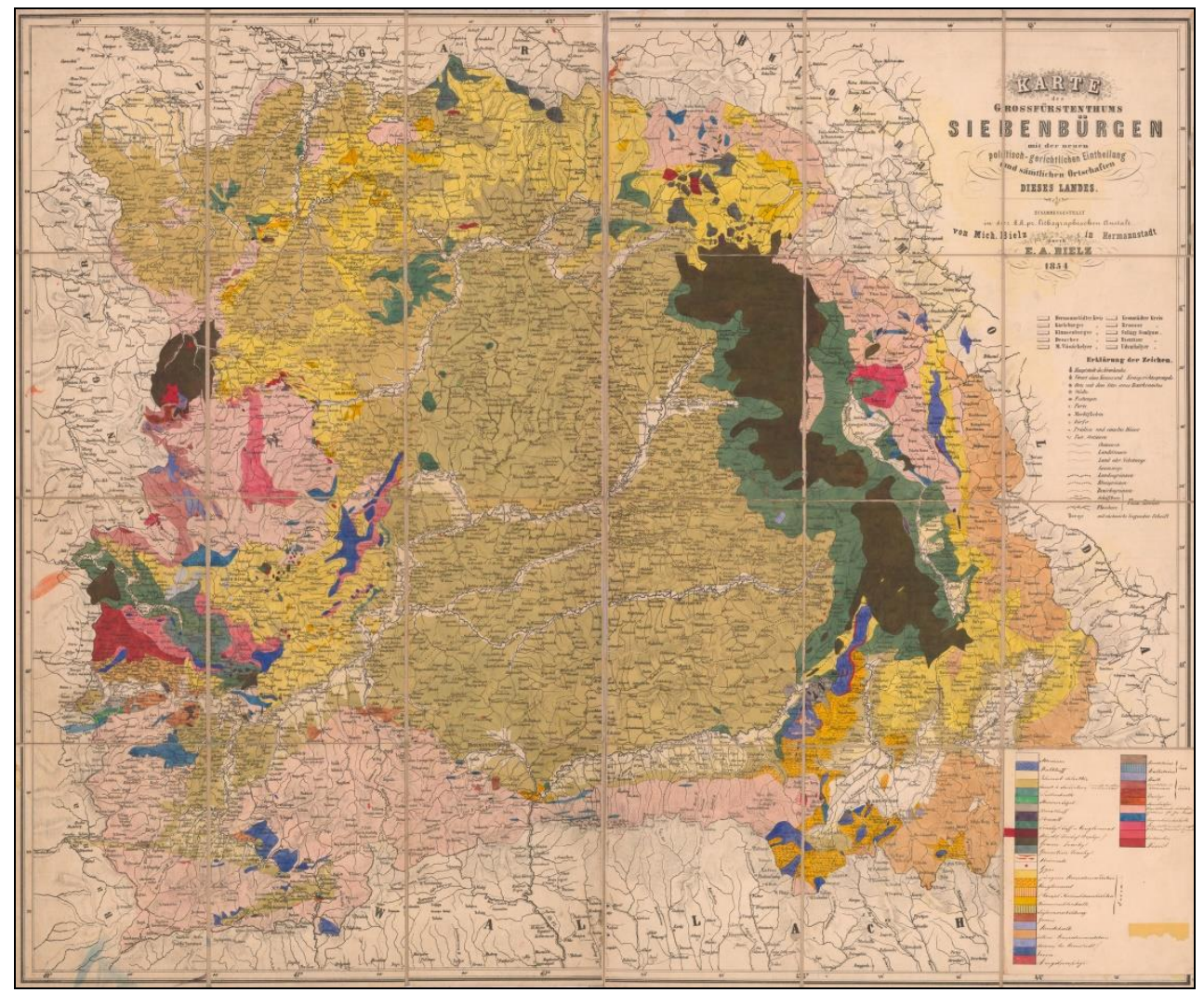

Fig. 1. Geologische Übersichts-Karte von Siebenbürgen, 1:576,000 (Hauer 1861).

Source: Collection of the Library of the Geological Survey of Austria.

The map was practically edited by Franz Ritter von Hauer based on the topographic map by Franz Fischer (1860) (Hauer,1860b; Hauer, 1863: 3-6), but in its compilation also took part Ferdinand von Richthofen, Dionys Štur, Guido Stache (Austrian geologists of the Imperial and Royal Geological Institute in Vienna) and Eduard Albert Bielz (secretary of the Transylvanian Society of Natural Sciences in Hermannstadt). As we have mentioned before, the authors divided the mapping work between themselves from a territorial point of view. Hauer mapped the Transylvanian part of the Eastern Carpathians, the Eastern part of the Southern Carpathians (Transylvanian Alps), to Turnu Roşu Gorge, as well as the middle part of the Apuseni Mounatins; Richthofen mapped the Northern part of Transylvania and the Harghita volcanic chain; Stache mapped the Northern part of the Apuseni Mountains, while Stur the Southern part of it and the Western part of the Southern Carpathians. During the geological surveying, the authors relied on Albert Bielz's guidance as well as on his first-hand knowledge of the territory (Hauer, 1863: 3-6).

The legend of the geological map of Transylvania by Hauer (1861) is based on the stratigraphic time scale classification system and distinguishes 35 different rock types and stratigraphic units by using different colours, lines and surface signs. At the same time the map is in accordance with the cartographic representation methods characteristic to the geological mapping of the second half of the nineteenth century. Finally we can notice the 
fact that according to the geological mapping of this period it evidences an extremely precise work in a geological sense. First of all, the map sharply distinguishes pyroclastics from lava flows in the case of the volcanic chain of the Eastern Carpathians; also, the presence and dispersion of the limestone olistolites in the Cretaceous series of the Southern part of the Apuseni Mountains are easily recognizable; and the age of the sediments increases from Southeast to Northwest etc. In any case, the map as well as the monograph closely connected to it can be considered landmark works which remained over half of a century (or even longer) the most important reference for researchers who studied the geology of Transylvania (Maxim, 1964).

\section{CARTOGRAPHIC ANALYSIS OF THE GEOLOGICAL MAP OF TRANSYLVANIA BY HAUER (1861)}

\subsection{Methods}

For an accurate geo-referencing of a map it is important to know or to assess its geodetic basis, especially as what regards the projection, geodetic datum and prime meridian used. However, the estimation of the topographic basis of the old maps can be often difficult, moreover in the case of the old geological maps which in general didn't have independent geodetic or topographic surveys (Galambos 2010a; Galambos 2010b) except for some large scale geological maps -, but they were compiled using as basis predesigned topographic or regional maps on which the geological data were subsequently drawn. Therefore, the first indispensable step for geo-referencing an old geological map is to assess the possible topographic map which could be used as topographic basis. In the case of the geological map of Transylvania by Hauer (1861) we have the answer to this question from the specialized literature, since Hauer himself wrote (Hauer, 1863: 3-6) that he used the map by Franz Fischer (1860) as topographic basis. Taking into consideration the scale of the map $(1: 576,000)$ as well as the year of publication (1860), we assumed that the topographic map by Fischer is a reduced map of the Second Military Survey.

The area covered by Second Military Survey of the Habsburg Empire involves 15 states today, thus it was necessary to create different triangulation networks with different reference points (Jankó, 2001; Timár \& Molnár, 2003; Timár et al., 2007). In Transylvania, the triangulation network was developed on the hybrid ellipsoid of Zach-Oriani (semimajor axis: $6376130 \mathrm{~m}$; semi-minor axis: $6355562.258 \mathrm{~m}$; inverse flattening: 1/310) (Varga, 2002; Timár \& Molnár, 2003). The origin was set to the observatory that functioned in that time on the hill of Dealul Ocna Sibiului, North-West of Sibiu (Ocna Sibiului datum) (Varga, 2002). The Molodensky-type transformation parameters between the Ocna Sibiului datum and WGS84 were determined by Timár Gábor and his colleagues (2004; 2007): $d X=+1734 \mathrm{~m}, \mathrm{dY}=+399 \mathrm{~m}, \mathrm{dZ}=+595 \mathrm{~m}$, while the point of origin in respect to the surface of reference was given by Varga (2002): $\varphi=45^{\circ} 50^{\prime} 25.13$ " (the latitude of the origin) and $\lambda=24^{\circ} 6^{\prime} 46.69^{\prime \prime}$ (the longitude of the origin, East from Greenwich). The above values in the case of longitude were initially given for the meridian of origin Ferro. The Ferro-Greenwich difference has been considered by us being of 17³9'46.02" (Timár \& Molnár, 2003). The geodetic datums and Molodensky-type transformation parameters of the maps compiled in the $19^{\text {th }}$ century are not introduced into GIS software, thus we needed to enter them manually (Korodi et al., 2015).

Although the Cassini-Soldner projection was used for the map sheets of the Second Military Survey on a scale of 1:28,800, the reduced maps on a scale of 1:576,000 and 1:288,000 were compiled using the Bonne projection (Jankó, 2007: 80-83). The exact 
parameters of the pseudoconical equal-area Bonne-projection are not known (Korodi et al., 2015). In the case of the geological map by Hauer (1861), we have defined the following: the longitude of the central meridian is $42^{\circ}$ East from Ferro, while the standard latitude is the $46.5^{\circ}$ parallel North. The rectification has been performed using Global Mapper v16.1, defining our control points in all crossings of the grid lines.

\subsection{Results and discussions}

The above described geo-referencing methods and projection parameters have been applied on the geological map by Hauer (1861) with the aim of rectifying it in its initial projection (and geodetic datum). The geometric accuracy as well as the distortions of the map have been analysed and visualised with the MapAnalyst 1.3.23 software application (Jenny \& Hurni, 2011).

As old map we imported the geo-referenced Hauer (1861) image, which was first reprojected into Mercator projection using Global Mapper v16.1 software. As new map we used the Open Street Map (in Mercator projection). Distortion grids, displacement vectors and circles, rotation angle and other statistical indicators and visualizations were computed with 17 pairs of corresponding points (we linked 17 towns recognized as control points) (Fig. 2).

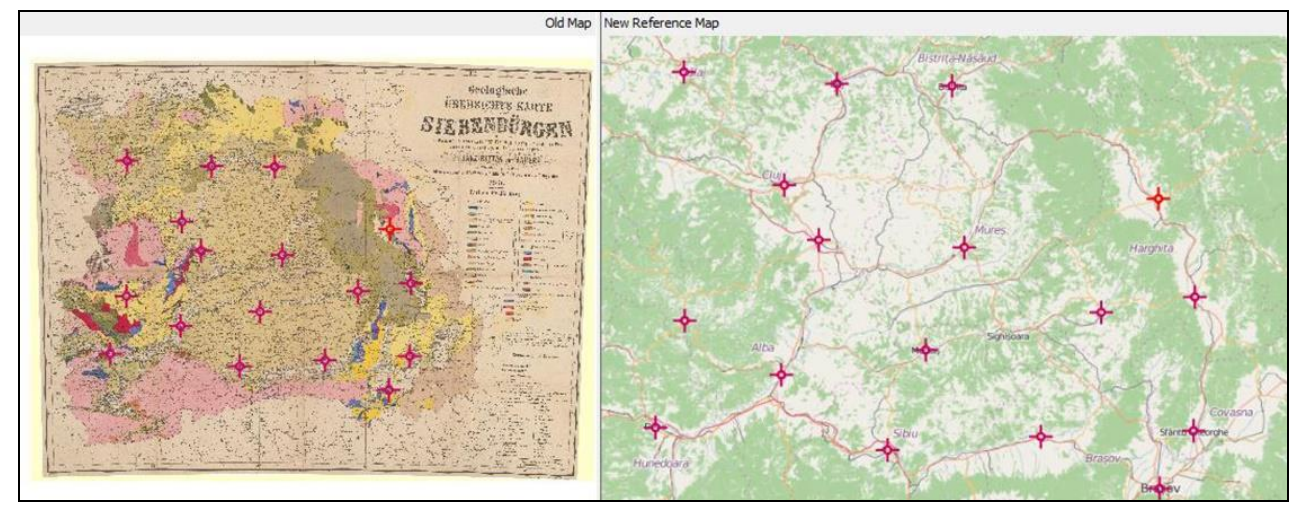

Fig. 2. The distribution of the control points on the map by Hauer (1861) (as old map) and on the Open Street Map (as new reference map) visualized in MapAnalyst.

We used the four-parameter Helmert transformation to match the coordinate systems. After computing, the results of transformation are the following: the error in rotation is only $0.117^{\circ}$, the standard deviation is $772 \mathrm{~m}$ (at the scale of the map: $1.34 \mathrm{~mm}$ !), the root mean square position error is $1092 \mathrm{~m}$, while the maximum difference is $2453 \mathrm{~m}$. The local variations of the displacements are graphically illustrated by the displacement vectors and circles (Fig. 3). We can notice the fact that the distribution of the displacement vectors is not systematic but accidental; therefore the distortions are not caused by the georeferencing problems, but they are mostly due to the surveying errors and printing techniques, to the small scale of the map, as well as to the post processing methods (e.g. reproduction and scanning) and to the manual introduction of the control points. 


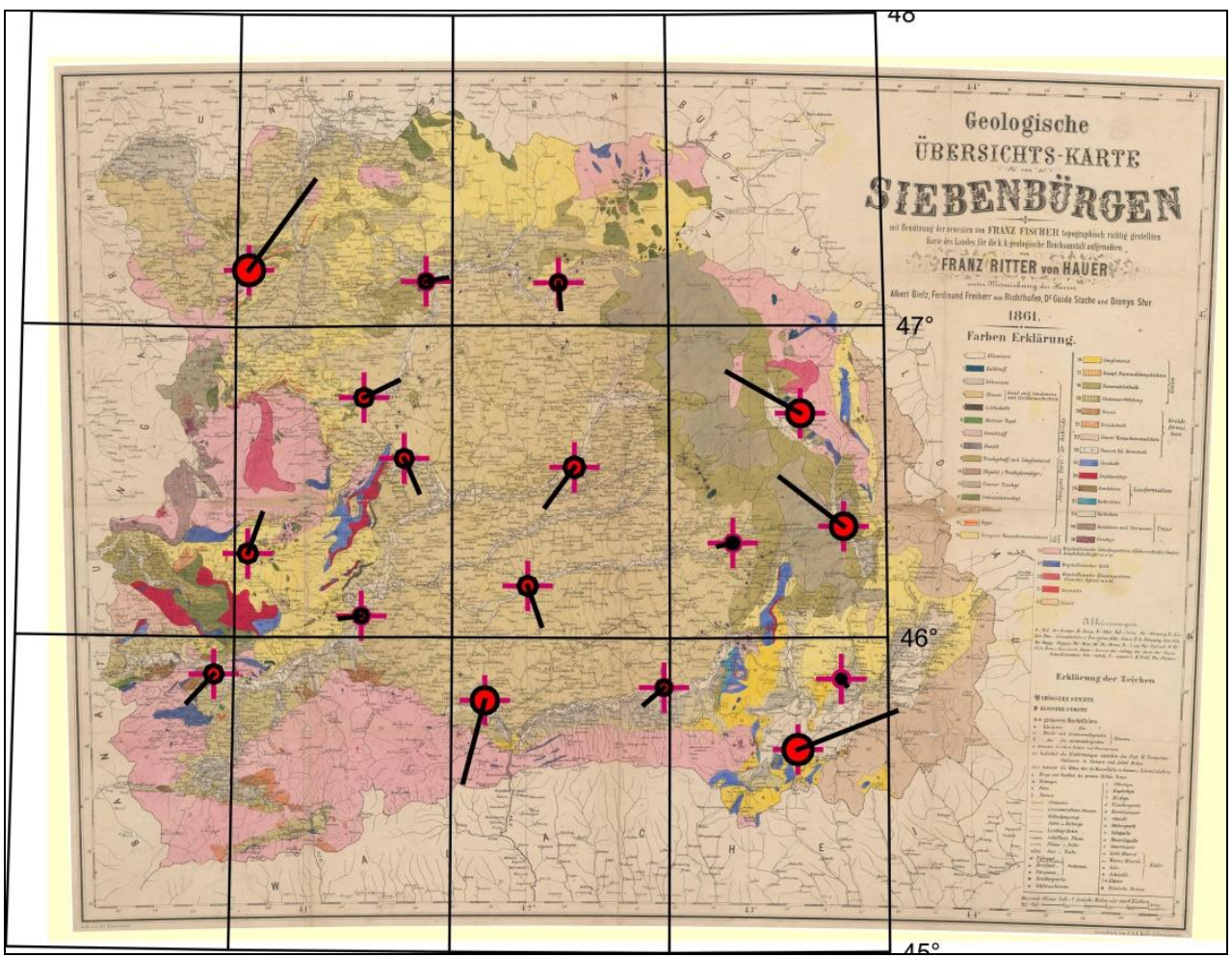

Fig. 3. Local variations of the displacements on the map by Hauer (1861) visualized in MapAnalyst. The scale factor of the displacement vectors and circles is 20 .

\section{CONCLUSIONS}

Old geological maps are part of our (thematic) cartographic heritage therefore their study is extremely important in the perspective of the history of geological mapping (or in a wider sense in the perspective of the history of science). Their availability in digital form makes them easily accessible for researchers therefore the attention of the scientific community can be truly drawn to their real cultural and professional value. Also, of exceptional practical importance is the analysis and exploration of their topographic basis (projections, geodetic datums, prime meridians), because it allows us to geo-reference them, and thus to integrate them into a GIS database. Beyond that, knowing their topographic accuracy is necessary for our further work to overlay several geological maps related to Transylvania - from different periods in order to extract geological information as well as to analyse and compare old geological data with modern ones, and consequently to track the evolution of geological knowledge in time.

\section{ACKNOWLEDGEMENTS}

The authors would like to thank Zsombor Bartos-Elekes, associate professor at the Babeș-Bolyai University, Faculty of Geography, for the advices concerning the accuracy analysis. 
This paper is a result of a doctoral research made possible by the financial support of the Sectorial Operational Programme for Human Resources Development 2007-2013, cofinanced by the European Social Fund, under the project POSDRU/187/1.5/S/155383 "Quality, excellence, transnational mobility in doctoral research".

\section{REFERENCES}

Bachl-Hofmann, C. (1999) Die Geologische Reichsanstalt von 1849 bis zum Ende des ersten Weltkriegs. In: Bachl-Hofmann, C. et al. (red.) Die Geologische Bundesanstalt in Wien: 150 Jahre Geologie im Dienste Österreichs (1849-1999). Wien, Böhlau, pp. 55-77.

Barczikayné Szeiler R., Gyalog L., Hegyiné Rusznyák É., Viktor Zs., Orosz L., Pentelényi A., Síkhegyi F. (2009) A földtani térképezés 140 éve - Térképválogatás a XVIII. századtól napjainkig, MÁFI kiadás - DVD. Budapest.

Brezsnyánszky K. (1996) Austro-Hungarian geological mapping before 1869. In: Dudich E. \& Lobitzer, H. (eds.) Advanses in Austrian-Hungarian Joint Geological Research. Budapest, pp. 25-32.

Brezsnyánszky K. (2001) Földtani térképezés: Terepi felvételezés - Térképi összegzés. Jegyzet a Nyugat-Magyarországi Egyetem Kitaibel Pál Környezettudományi Doktori Iskola hallgatói számára. Budapest.

Brezsnyánszky K. (2007) Geological maps. Nova Acta Leopoldina NF 94, 349, 71-79.

Brezsnyánszky K. \& Turczi G. (1998) Geological Maps - from Litography to GIS. Földtani Közlöny, $128(1), 145-156$.

Brezsnyánszky K., Dudich E. \& Schedl, A. (1999) Ungarn. In: Hofmann, T., Die geologische Untersuchung des Keiserreiches. In: Bachl-Hofmann, C. et al. (red.) Die Geologische Bundesanstalt in Wien: 150 Jahre Geologie im Dienste Österreichs (1849-1999). Wien, Böhlau, pp. $125-129$.

Fischer F. (1860) Karte des Grossfürstenthums Siebenbürgen nach der neuesten Landeseintheilung, 1:576,000. Hermannstadt.

Galambos Cs. (2009) History of the Hungarian Geological Maps - An Overview from the $18^{\text {th }}$ Century to Nowadays. In: Gartner, G. \& Ortag, F. (eds.) Proceedings of the First ICA Symposium for Central and Eastern Europe 2009, Vienna University of Technology, Vienna. pp.713-724.

Galambos Cs. (2010a) Projection analyzis and geo-reference of the old Hungarian geological maps. In: Gartner, G. \& Livieratos, E. (eds.) Proceedings of the $5^{\text {th }}$ International Workshop on Digital Approaches in Cartographic Heritage, Vienna University of Technology, Vienna. pp. 183-188.

Galambos Cs. (2010b) Topographic basis and prime meridians used in historical Hungarian geological maps. Geophysical Research Abstracts, 12 EGU2010-3851.

Haidinger, W. (1859) Ansprache gehalten am Schlusse des ersten Decceniums der Kaiserlichköniglichen Geologischen Reichsanstalt in Wien am 22. November 1859. Wien, K. K. Hof- und Staatsdruckerei.

Hauer, F. (1859) Vorlage einer geologischen Uebersichtskarte des östlichen Siebenbürgen / Sitzung am 29. November 1859. Jahrbuch der k. k. Geologischen Reichsanstalt, 10, 180-183, Wien. [Online] Available from: http://opac.geologie.ac.at/ais312/dokumente/VH1859_180_A.pdf [Accessed 30th March 2016].

Hauer, F. (1860a) Höhenmessungen in Siebenbürgen. Mittheilungen der Kaiserlich-Königlichen Geographischen Gesellschaft, 4, 7-36, Wien. [Online] Available from: http://opac.geologie.ac.at/ais312/dokumente/MGgGW_004_Hauer_007_036.pdf [Accessed 30th March 2016].

Hauer, F. (1860b) Vorlage der vollendeten geologischen Uebersichtskarte von Siebenbürgen. Jahrbuch der k. k. Geologischen Reichsanstalt, 11, 137-138, Wien. [Online] Available from: http://opac.geologie.ac.at/ais312/dokumente/VH1860_137_A.pdf [Accessed 30th March 2016].

Hauer, F. (1861) Höhenmessungen im westlichen Siebenbürgen. Mittheilungen der KaiserlichKöniglichen Geographischen Gesellschaft, 5, 1-23, Wien. [Online] Available from: 
http://opac.geologie.ac.at/ais312/dokumente/MGgGW_005_Hauer_001_023.pdf [Accessed 30th March 2016].

Hauer, F. (1861) Geologische Übersichts-Karte von Siebenbürgen, 1:576,000. Hermannstadt.

Hauer, F. (1863) Vorwort. In: Hauer, F. R. \& Stache, G. (red.) Geologie Siebenbürgens. Wien, Wilhelm Braumüller K. K. Hofbuchhändler, pp. 3-6.

Hauer, F., Bielz, A. \& Hörnes, M. (1860) Geologische Aufnahmen und Untersuchungen im Felde: Siebenbürgen [fingierter Title]. Jahrbuch der k. k. Geologischen Reichsanstalt, 11, 113-114, Wien.

Hauer F. \& Stache G. (1863) Geologie Siebenbürgens. Wien, Wilhelm Braumüller K. K. Hofbuchhändler.

Jankó A. (2001) A második katonai felmérés. Hadtörténeti Közlemények. [Online] 114, 103-129. Available from: http://epa.oszk.hu/00000/00018/00016/04janko.htm [Accessed 17th March 2016].

Jankó A. (2007) Magyarország katonai felmérései 1763-1950. Budapest, Argumentum.

Jenny, B. \& Hurni, L. (2011) Studying cartographic heritage: Analysis and visualisation of geometric distorsions. Computers \& Graphics, 35-2, 402-411.

Korodi E., Bartos-Elekes Zs., Rus, I., Haidu, I. (2015) Cartographic analysis of some old Transylvanian geological maps from the second half of the nineteenth century. Acta Geodaetica et Geophysica. [Online] Available from: doi:10.1007/s40328-015-0133-5 [Accessed 17th March 2016].

Maxim, Al. (1964) O sută de ani de la apariţia monografiei geologice a Transilvaniei „Geologie Siebenbürgens" de Fr. Hauer şi Guido Stache. Studia Universitatis Babeş-Bolyai, Series Geologia-Geographia, IX (1), 57-67.

MGI (1863) General-Karte des Grossfürstenthums Siebenbürgen, 1:288,000. Wien, Militärgeographisches Institut.

Pentelényi A. \& Síkhegyi F. (2012) Hazai földtani térképeink topográfiai alapjai. A MÁFI évi jelentése 2010, Budapest. pp. 81-95.

Timár G. \& Molnár G. (2003) A második katonai femérés térképeinek közelítő vetületi és alapfelületi leírása a térinormatikai alkalmazások számára. Geodézia és Kartográfia, 55(5), 27-31.

Timár G., Telbisz T. \& Székely B. (2003) Ürtechnológia a digitális domborzati modellezésben SRTM adatbázis. Geodézia és Kartográfia, 55(12), 11-15.

Timár G., Molnár G., Păunescu, C., Pendrea, F. (2004) A második és harmadik katonai felmérés erdélyi szelvényeinek vetületi- és dátumparaméterei. Geodézia és Kartográfia, 56(5), 12-16.

Timár G., Molnár G., Imecs Z., Păunescu, C. (2007) Datum and projection parameters for the Transylvanian sheets of the $2^{\text {nd }}$ and $3^{\text {rd }}$ military surveys. Geographia Technica, 1, 83-88.

Varga J. (2002) A vetületnélküli rendszerektöl az UTM-ig. Kézirat. BME, Budapest.[Online] Available from: http://www.agt.bme.hu/staff_h/varga/Osszes/Dok3uj.htm [Accessed 17th March 2016].

Werner, M. (2001) Shuttle Radar Topography Mission (SRTM), Mission overview. Journal of Communication (Frequenz, 55, 75-79. Available from: doi: 10.1515/FREQ.2001.55.3-4.75 [Accessed 15th Apryl 2015]. 